(The following is an electronic version of an article that will appear in the British Journal for the History of Philosophy, 2012.)

\title{
Leibniz in the eighteenth century: Herder's critical reflections on the Principles of nature and grace
}

Nigel DeSouza

The impact of Leibniz in the eighteenth century is usually seen through the prism of the Leibniz-Wolffian philosophy in general or through the fate of particular Leibnizian ideas such as the concept of pre-established harmony, the notion of the best of all possible worlds', or the theory of the monadology itself. If Leibniz's philosophy is taken as a whole, however, few eighteenth century thinkers were more deeply influenced by it than Johann Gottfried Herder. ${ }^{1}$ Above all, Herder's ontology and epistemology draws more on Leibniz than on any other philosopher. While elements of this intellectual debt will become apparent in what follows, the subject of this article is narrower in scope. ${ }^{2}$ Its significance for the history of philosophy, however, is anything but narrow.

Interestingly, the most significant aspect of Leibniz's influence on Herder is to be found in the one area where Herder vehemently disagreed with Leibniz (as well as Descartes and Spinoza) ${ }^{3}$ : the soul-body relationship. Herder worked out the philosophical underpinnings of his thought, to which he would remain faithful for the rest of his life, over the course of several short works in the 1760s. In one of these, Ueber Leibnitzens Grundsätze (1769), he lays out his reasons for rejecting Leibniz's theory of the preestablished harmony of soul and body. Ueber Leibnitzens Grundsätze has received some attention in the secondary literature, in which Herder's critical stance towards Leibniz has been uncovered, but the full significance of the text has not been appreciated nor has it been subjected to a detailed exposition. In addition, Alain Renaut's recent engagement with this text, in contrast, fails to grasp Herder's critical engagement with Leibniz, most notably the former's rejection of the windowlessness of monads, and instead erroneously

\footnotetext{
${ }^{1}$ See, e.g, Arnold (2005); Kondylis (1981) 576ff. 615ff.; Heinz (1994) passim.

${ }^{2}$ A detailed study of Herder's early relationship to Leibniz is one of the tasks of my project, The philosophy of the young Herder, currently in preparation.

${ }^{3}$ See, e.g., Herder, Vom Erkennen und Empfinden den zwo Hauptkräften der Menschlichen Seele (1775), SWS, VIII, 266. The abbreviations used in this paper are indicated in the bibliography.
} 
portrays Herder as remaining faithful to Leibniz's monadology. ${ }^{4}$ Indeed, the linchpin in Herder's argument in Ueber Leibnitzens Grundsätze is the rejection of the windowlessness of monads. Why and how this rejection was so obvious to Herder is explained below, a major part of the explanation involving how it had come to be so by his time. There are two parts to Herder's rejection of the windowlessness of monads. The first is the acceptance of real interaction between material substances, for which Herder drew on Wolff, Crusius, and especially the pre-critical Kant. The second is the belief in soul-body interaction. While this too had figured in the writings of Crusius and Kant, among others, Herder's originality lies in his particular conception of the soul-body relationship.

Philosophers in the eighteenth century operated within the same basic framework as Descartes and Leibniz in their reflections on the soul-body relationship, namely, that in which the soul and body were conceived of either as two distinct substances which needed to be related to each other (Descartes) or as a dominant monad and aggregate of monads, respectively, with purely ideal and expressive relations (Leibniz). The solutions of influx, occasionalism, and pre-established harmony bear witness to this fact. However, while Leibniz's pre-established harmony explicitly denied any real interaction between soul and body, the relationship between the two was intimate. For Leibniz, no soul existed without a body and the soul-monad was the principle of organization and movement of the body, even if the body's actual movements and development were purely the efficient result of its own previous mechanical states and its unfolding qua complex preformed natural machine. ${ }^{5}$ Herder agreed with the intimate connection Leibniz saw between the soul and body but rejected the idea of the body as responsible entirely for its own movement and growth. Leibniz of course had his reasons for his theory (the law of conservation of force, principle of substantial unity, principle of causal selfsufficiency) but these no longer resonated with Herder. While this is also true of other eighteenth century thinkers, who developed new theories of physical influx, Herder took a different tack and, as it were, merely modified Leibniz's own theory to allow for real interaction between the soul and body. That is, instead of seeing the solution in terms of

\footnotetext{
${ }^{4}$ See, e.g., Dreike (1973) 60ff.; Kondylis (1981) 623ff.; Zippert (1994) 171, 173, 175; Renaut (2000) 33.

${ }^{5}$ The relevant question of Leibniz's purported idealism and its reception in the eighteenth century is briefly discussed below.
} 
how two distinct substances could be made to interact, Herder conceived of the soul as always attached to a body and intimately bound up with it, forming its principle of organization and motion via genuine interaction.

In this way, Herder can be seen to be returning to a more squarely Aristotelian conception of the soul as the principle of life and substantial form of the body, although mediated by important modern shifts. Chief among these is Herder's acceptance of the soul's essential nature as thinking substance. Herder's theory of the soul-body relationship emerges out of the combination of these two conceptions: the soul, as thinking substance, realizes its essential nature by constructing itself a body through which it interacts with, and through whose senses it acquires knowledge of, the external world. Whereas Leibniz had rehabilitated substantial forms in order to explain his dynamics through which the motion inherent in matter could be made comprehensible, Herder dispenses with this role for substantial forms (thanks to his Newtonian-Kantian conception of matter endowed with forces of attraction and repulsion) and restricts them, like Aristotle, to the living realm. Herder is consequently unique among his predecessors and contemporaries in explaining the phenomenon of life not by recourse to plastic natures, hylarchic principles, or moules intérieurs, but rather by a modern-inflected conception of the soul as principle of life, eventually supplemented by his later endorsement of epigenesis. The importance of this aspect of his originality cannot be overestimated. It is not only the foundation of his conception of Bildung, Kultur, and his philosophy of history; it is also the innovation responsible for his later influence on German Idealism. ${ }^{6}$

Herder's Ueber Leibnitzens Grundsätze von der Natur und Gnade comprises a series of five numbered critical reflections on elements in the first four numbered paragraphs of Leibniz's Principes de la Nature et de la Grace, fondés en raison. Leibniz opens the Principes with the statement: 'A substance is a being capable of action' and proceeds to define simple substances as having no parts and composite substances or bodies as consisting of collections of such simple substances. Leibniz further defines

\footnotetext{
${ }^{6}$ On this see esp. Kondylis (1981) 537ff., 576ff. See also Heinz (1997).
} 
these simple substances as lives, souls, and minds, as unities. ${ }^{7}$ Here is Herder's corresponding first reflection in its entirety:

If a substance is an entity capable of activity, should not, from its ground, an influence on other substances immediately follow? That it is a unity, what can this mean other than that outside it there can be other unities, pure simple unities, which already have a relationship to each other according to their essence: otherwise God himself could not establish one in them: otherwise each Monad would be a world unto itself and with no other communicable. ${ }^{8}$

Already with this opening salvo, Herder is announcing his commitment to a distinctly eighteenth-century metaphysical framework for understanding the physical world, which gradually emerged through the works of, among others, Christian Wolff, Christian August Crusius, and the pre-critical Kant. This framework is of fundamental importance to Herder's theory of the soul-body relationship; the above reflections thus need to be carefully unpacked. Two shifts in particular need to be understood in order to grasp the full implications of Herder's opening reflection: 1) from the Leibnizian conception of the world as an ideal whole to the conception of it as a real whole, 2) from the Leibnizian conception of the monad as immaterial to the conception of material monads.

The first shift from a Leibnizian framework implied in Herder's comments is that of construing the world as a real whole, as opposed to an ideal whole. Leibniz would not disagree with the claim that monads have a relationship to each other according to their essence; but he construes this relationship as expressive. ${ }^{9}$ By positing that a substance's activity should necessarily entail influence on other substances, Herder is rejecting Leibniz's commitment to purely ideal intersubstantial relations. Herder was most likely first introduced to the idea of the world as forming a real whole through the works of Crusius, whom Kant included in his metaphysics lectures at the University of Königsberg, which Herder attended from 1762 to 1764. In his notes from those lectures, Herder writes, 'The world is a real whole: all things stand in it in real connection'. ${ }^{10}$

\footnotetext{
${ }^{7}$ Principes de la nature et de la grace, 207, GP, VI, 598 (hereafter cited as PNG).

${ }^{8}$ Ueber Leibnitzens Grundsätze, SWS, XXXII, 225 (hereafter cited as ULG). The text is also usefully reproduced in Herder (1987).

${ }^{9}$ See esp. Système nouveau pour expliquer la nature des substances et leur communications entre elles, aussi bien que l'union de l'ame avec le corps, GP, IV, 477-87.

${ }^{10}$ Metaphysik Herder, AA, XXVIII, 39 (hereafter cited as MH). Cf. Crusius (1745) 657, § 350: 'Der

Begriff einer Welt überhaupt muß also dieser seyn: eine Welt heißt eine solche reale Verknüpfung
} 
Crusius maintains that the mere existence of substances necessarily entails their causal mutual connection. For no other form of connection is possible once you move beyond their ideal connection in thought and posit their real existence. ${ }^{11}$ In the lecture notes, however, Kant repeats the same criticism of Crusius he had previously published in his Nova dilucidatio of 1755. His argument is that the mere existence of substances does not entail their causal or any other kind of interaction whatsoever, for God must in addition establish how, if at all, created substances will relate to each other. In the words of the Principle of Coexistence in the 1755 treatise: 'Finite substances do not, in virtue of their existence alone, stand in a relationship with each other, nor are they linked together by any interaction at all, except in so far as the common principle of their existence, namely the divine understanding, maintains them in a state of harmony in their reciprocal relations. ${ }^{, 12}$ And since this principle is entirely a matter of choice for God, he might even decide that substances should be in no place and thus under no relations at all. ${ }^{13}$ But this was not the pre-critical Kant's final position on the subject. In his 1763 work, Der einzig mögliche Beweisgrund des Daseins Gottes, Kant asserts that because of the very possibility and essence of matter, which is included in the divine understanding itself and is thus non-morally dependent on God, i.e., not subject to God's will, as soon as the decision to create matter is taken, the laws of motion of matter follow with 'logical necessity of the highest kind'. ${ }^{14}$ Kant thus returns to a position closer to Crusius', but now

endlicher Dinge, welche nicht selbst wiederum ein Theil von einer andern ist, zu welcher sie vermittelst einer realen Verknüpfung gehörte.'

${ }^{11}$ Crusius (1745) 160, § 94: '[...] jedwede Vereinigung zufälliger Dinge, welche ausserhalb der Gedancke eine reale unio existentialis seyn soll, auf einer Causal-Verknüpfung der Dinge beruhen müsse, vermöge deren zum wenigsten eines gegen das andere thätig wircken muß, wiewol auch beyde wechselsweise gegen einander thätig seyn, und auch wechselsweise von einander leiden können. Denn est ist sonst nichts anders ausserhalb der Gedanke möglich, was einen Grund der Vereinigung zwischen vollständigen Dingen abgeben kann. Sobald man dahero dieses hinweg nimmt, so muß man sie nur durch einen Begriff im Verstande vereinigen, d.i. die Dinge haben alsdenn entweder gar keine oder doch nur eine bloß ideale Vereinigung.' This point of difference between Kant and Crusius is explored in detail in Watkins (2005) $85-9,145 \mathrm{ff}$.

12 AA, I, 412ff. Cf. MH, 51: 'Zum Nexu der Dinge im Ganzen gehören nicht blos die Exsistenzen der Dinge [...] Es wird also noch waz besonders mutua actio zur Verknüpfung erfordert.' See also MH, 88788: 'Alle Welt Substanzen konnten nicht in nexu, ohne ein 3tes zu sezzen, daß sie verbunden.'

${ }^{13} \mathrm{AA}, \mathrm{I}, 414$.

14 AA, II, 100. Cf. Reich (2001) 298ff. on how this shift is based on Kant's abandoning a Wolffian conception of space as dependent on the activity of substances in it and thus of possibly different kinds of space or no space at all (prior to 1755) to an acceptance of a conception of one kind of space which is determined by the structure of matter itself (1762 onwards). Given that this new conception can also be discerned in Herder's lectures notes (see, e.g., MH, 44ff), it is unclear why in 1762 Kant is still criticizing 
armed with a theoretical advantage of a clear justification for why the mere existence of substances necessarily entails their connection and interaction. It is against this background that Herder's claim that substances or unities already have a relationship to each other according to their essence should be understood.

The foregoing discussion seems to involve some conceptual ambiguity which also needs to be cleared up: for surely, it will be asked, physical matter is not to be simply identified with 'substance' or 'unity' or even 'monad'? By the time Herder composed his reflections on Leibniz, however, the notion of 'physical monads' was well-established. In Herder's lecture notes, we see Kant's particular hypothesis on this topic, first published in his 1756 Monadologia Physica, namely, that an unextended monad's impenetrability, and hence spatial extension and solidity, is derived from the activity of its repulsive force. ${ }^{15}$ Kant's theory was the culmination of a process which began with Christian Wolff's doubts expressed to Leibniz, which Herder duly noted, ${ }^{16}$ about all monads having the same kind of force, that is, a force of representation, and whether the element of bodies should not rather have a 'force of bodies' which shows itself in movement. ${ }^{17}$ This process raises important questions about the understanding of Leibniz in the eighteenth century, in particular, to what extent eighteenth century thinkers believed Leibniz was an idealist and what this belief amounted to precisely, a question that remains unresolved in our own day and which has recently been the subject of renewed and lively debate. ${ }^{18}$ Nevertheless, it is relatively clear that the most widespread interpretation of Leibniz in the eighteenth century was that the derivative forces of aggregates of unextended and immaterial monads ground bodies as well-founded phenomena possessing both motion and

Crusius' theory on the basis of the principle of coexistence, as we saw above, which entails a conception of space he had by this time abandoned. See, e.g., MH, 888: 'Der Raum muß der 1 te actus der göttlichen Allgegenwart seyn: wodurch die Dinge in nexus kommen: der Raum macht beziehung.'

${ }^{15} \mathrm{MH}, 44 \mathrm{ff}$.

${ }^{16}$ A few passages of Herder's Wahrheiten aus Leibnitz, which mainly consist of his German summary of sections of Leibniz's Nouveaux essais, contain commentary by Herder, and one of these passages is based on Abraham Kaestner's Preface to Eric Raspe's 1765 edition of Leibniz's Oeuvres philosophiques (including the Nouveaux essais). In this passage, Herder writes: 'Die Vorstellungskraft aller Elemente hat auch Wolf nicht annehmen wollen' (SWS, XXXII, 211); cf. Kaestner (1765) v.

${ }^{17}$ Wolff (1740) 369, § 215. Cf. Wolff (1751) 370-1, §600.

${ }^{18}$ The best recent study rejecting Leibniz as idealist is Phemister (2005) which critically engages, among others, Adams (1994). 
impenetrability and subject to laws of motion. ${ }^{19}$ The shift to material monads and bodies, as well as space, as real is, of course, the product of Newton.

Kant's whole pre-critical period has been seen as one long attempt to reconcile Newton's physics with Leibniz's metaphysics. ${ }^{20}$ Kant's various reflections on the relationship between substances, starting with his 1747 Gedanken von der wahren Schätzung der lebendigen Kräfte, are thus always primarily oriented towards grounding the interaction between material things. Going hand in hand with his physical monadology is Kant's famous nebular hypothesis according to which the physical universe in all its order and harmony evolved entirely as a result of the operation of the forces of attraction and repulsion inherent in matter and the laws of motion to which they give rise, as laid out in both the Allegemeine Naturgeschichte und Theorie des Himmels (1755) as well as the later Einzig möglicher Beweisgrund. The subtitle of the former even reads: 'oder Versuch von der Verfassung und dem mechanischen Ursprunge des ganzen Weltgebäudes, nach Newtonischen Grundsätzen abgehandelt'. The young Herder fully adopted this theory, as is clear from several of his early writings, including the Grundsätze der Philosophie (1769), where he speaks of the planets being formed by the forces of attraction and repulsion. ${ }^{21}$

Against this background, the full implications of Herder's reflections in the first section of his Ueber Leibnitzens Grundsätze can be appreciated. The substances or 'simple unities' which Herder speaks of are most plausibly construed of here as material monads. Substances are related to each other via the forces of attraction and repulsion which connect the entire physical universe and make it a whole. These relations result from the very essence or nature of substances, for otherwise God could not bring any such relation into being: Herder is agreeing here with the Kant of the Einzig möglicher Beweisgrund that the internal possibility of matter and the laws of motion which

\footnotetext{
${ }^{19}$ Herder himself notes, in the same passage quoted in f.n. 16 above, and again based on Kaestner (1765) iii-iv, Leibniz's conception of body as 'aus einfachen Theilen zusammengesetzt' and that 'wir uns in ihm [i.e., body] eine große Anzahl unausgedehnter Wesen verworren vorstellen' (SWS, XXXII, 211). This speaks more to the nature of our epistemological access to bodies rather than to their ontological status as real or ideal. Kaestner himself interprets Leibniz this way in the corresponding section of the Preface through the analogy of eyes which are too weak to see the individual stars which appear to us as a 'luminous patch' rather than composing the patch as parts do a whole; see Kaestner (1765) iv.

${ }^{20}$ See, e.g., Friedman (1992) $1-52$ and Schönfeld (2000) who even identifies this reconciliation as Kant's 'pre-critical project'.

${ }^{21}$ SWS, XXXII, 229.
} 
necessarily follow from it are non-morally dependent on God. The activity of these substances thus necessarily also entails their capacity to have a real effect on and change (einwirken) other substances. Moreover, without these real relations, Herder adds, each monad would be a world unto itself, incommunicable with any other monad. Here too, Herder is showing his agreement with Kant that the changes in a monad must involve something external, but this final line of the first numbered paragraph marks a shift in Herder's focus from substances or monads in general to the soul or Leibniz's soul-monad in particular which will form the object of Herder's attention for the remainder of this short work.

The upshot of the first section of Ueber Leibnitzens Grundsätze is a rejection of the Leibnizian theory of dynamics according to which there is no real interaction between bodies, and where bodies instead always move as a result of their own derivative active force on the occasion of an impact by another body or a volition of the soul (and where all those movements - whether caused by another body or the soul - are fully determined in terms of efficient causation by the series of previous mechanical states of the body and in terms of final causation by the laws of these series in the entelechies governing the aggregate of corporeal substances which constitute it). Leibniz's axiomatic commitment to the self-sufficiency, including causal self-sufficiency, of a substance, which admitted no external source of change of its state, simply no longer resonated among eighteenthcentury thinkers who had experienced the Newtonian shift. It is important to grasp accurately the difference between these eighteenth century thinkers and Leibniz. Leibniz's mechanics, which plays out on the level of derivative active and passive forces, involves laws of motion relating to the movement and collision of bodies and transfers of force between bodies. For Leibniz, however, this interaction is only apparent-in fact, upon receiving impact, elastic bodies (the only kind for Leibniz) compress and rebound as if as a direct result of that impact but in fact each body moves entirely as a result of its own derivative active force, grounded in the primitive active forces of the metaphysical substances underlying it which change in accordance with the pre-established harmony. ${ }^{22}$ In this way, the law of conservation of force and the principles of substantial unity and

\footnotetext{
${ }^{22}$ For discussion, see Duchesneau (1994) 238ff., Garber (2009) 129-140. The term 'metaphysical substances' as opposed to 'monads' reflects the fact that Leibniz's dynamics precedes his later development of the monadology.
} 
causal self-sufficiency are preserved. Eighteenth century thinkers, in contrast, dispense with this metaphysical dimension as conceived by Leibniz and construe the interaction between bodies as real, not merely apparent.

Herder's rejection of the impossibility of real intersubstantial causation in Leibniz's philosophy, or of the windowlessness of monads, extends to Leibniz's theory of the relations between the soul and the body, which he explores in the remainder of Ueber Leibnitzens Grundsätze. Leibniz writes in $\S 2$ of the Principes that a monad is distinguished from another monad 'only by its internal qualities and actions, which can be nothing but its perceptions (that is, the representation of the composite, or what is external, in the simple) and its appetitions (that is, its tendencies to go from one perception to another) which are the principles of change'. ${ }^{23}$ With seeming approval Herder repeats this claim of Leibniz's in the opening of his own second paragraph: '[i]n every monad, there must be different qualities; these are nothing other than perceptions: representations of the composite, the external'. In doing so, Herder expresses his agreement with defining the soul at least in part by its mental power or faculty of representation. ${ }^{24}$ But he is then quick to part company, continuing:

How are these produced from the inner force of the soul, entirely in abstraction from the external which exists? Where does the idea come from that a soul could perpetually dream up a world for itself, from its inner force, without this world existing, without the soul being able to contribute the slightest thing to its existence? Thus would thought be nothing real; it would be an image without a thing, a thing without being a thing; would this not thus be a contradiction? ${ }^{25}$

Analogously to his rejection of a body's own power to move itself, Herder dismisses the idea that a soul's perceptions can be entirely internally generated. Insofar as the perceptions are of an external world, they are most certainly not products of the soul itself, nor is their sequence governed by an inner principle of change qua appetition. It would be wrong to say that Herder rejects altogether an inner principle of change in the soul, as we shall see below. And it is also clear that he agrees with Leibniz's Platonist epistemology to the extent that he rejects the notion of the soul as a tabula rasa and

\footnotetext{
${ }^{23}$ PNG, 598.

${ }^{24}$ The Grundsätze der Philosophie opens with the statement: 'Ich denke; dies Denken ist meinem innern Ich so eigen, als dem Körper die Bewegung: ich kanns also als dasselbe in der Seele betrachten, was bei den Körpern die Bewegungs- und Fortrückungskraft ist.' SWS, XXXII, 227.

${ }^{25}$ ULG, 225-6.
} 
accepts Leibniz's conception of it as a veined marble. ${ }^{26}$ But there is no getting around the fact that as between bodies, Herder resolutely rejects any pre-established harmony between body and soul whereby the soul's primitive active force is the sole source of its perceptions. At the same time, Herder opposes as much as Leibniz the construal of any such connection along the lines of a physical influx whereby there is an intersubstantial transmigration of accidents. ${ }^{27}$ In other works, Herder provides a detailed account of how the soul's perception of the external world begins with sensuous formulae via the sensuous media of light, sound, etc. ${ }^{28}$ The intelligibility of this epistemology is also premised on the nature of the ontological relationship between soul and body and the soul's presence in the body, which is the focus of Ueber Leibnitzens Grundsätze and which we further explore below. The conclusion of $\S 2$ amounts to the updated Cartesian one that without there being a real connection between the soul and the outside world, we are deceived in our thoughts and images of this world and it is as if God alone is their eminent cause. $^{29}$

Paragraph 3 takes up the question of how a multiplicity of changes can exist in the simple substance that is a monad. Again, Herder has Leibniz's soul-monad primarily in mind, as does Leibniz in the relevant passages of his Principles which Herder is engaging with here. After explaining that the monad's changing perceptions and appetitions are internally generated, Leibniz continues: "[f]or the simplicity of substance does not prevent a multiplicity of modifications, which must be found together in this same simple substance, and which must consist in the variety of its relations to external things. Similarly, in a center or point, though entirely simple, we find an infinity of angles formed by the lines that meet there. ${ }^{30}$ Herder begins by restating Leibniz's claim: '[i]n the simplicity of the substance there is at all times a multiplicity of modifications', but then he immediately asks, 'where does this multiplicity in such a perpetual dream of a simple soul come from? ${ }^{31}$ Again, the windowlessness of Leibniz's monads is put in

\footnotetext{
${ }^{26}$ See especially his 1766/1768 piece Plato sagte: daß unser Lernen bloß Erinnerung sei in Heinz (1994) $175-82$.

${ }^{27}$ See e.g. Leibniz, Système nouveau, GP, IV, 484 and 'Preface to an edition of Nizolius', L 126.

${ }^{28}$ See esp. Plato sagte and the three versions of Vom Erkennen und Empfinden der menschlichen Seele (1774, 1775, 1778), SWS, VIII. See also Heinz (1994) 43-79, 109-173 and Clairmont (2009) 43-64.

${ }^{29}$ Cf. Descartes, Méditations, AT, 79-80.

${ }^{30}$ PNG, 598.

${ }^{31}$ ULG, 226.
} 
question. Herder claims that in a power of thought which is closed in on itself, has no communication with other substances, and acts from its own ground, he can at most conceive of its train of thoughts as a line. The problem, however, is that in a line there is merely a multiplicity next to each other; that is, a line is not simple and thus cannot correspond to a simple substance. Leibniz's image of the mind as a point with its relations to external things conceived of as the infinity of angles formed by the lines that meet at it thus seems like the right one. However, the problem for Herder is that this model of the relations is purely ideal: the perceptions of the mind arise as if those relations were real. But as Leibniz explains in the Monadologie, even if the mind were to be construed of as a machine writ large, nothing among its mechanical parts would explain perception itself, which is thus only found in a simple substance, a conclusion which is consonant with Leibniz's commitment to both the unity and causal selfsufficiency of substance. ${ }^{32}$ This inability to account for perception mechanically, however, has no effect on the nature and content of those perceptions, which both contain multiplicities simultaneously and which follow one after the other according to appetition. That is, while the relations between the mind and the world for Leibniz are indeed ideal as in the mathematical model, the mind is not a mathematical ideal point but a real metaphysical point possessing multiple perceptions. ${ }^{33}$ For Herder, however, there exists no essential incompatibility between the simplicity of the mind and its real relationship to the external world. On the contrary, both the sequence of the soul's perceptions and the multiplicity in each of them requires the latter. Herder thus devises a way out using Leibniz's own terms, suitably revised:

An in-each-other cannot be grasped in a mathematical point: and even less so a multiplicity of modifications, in a simple substance, which is considered entirely on its own. But if the latter is to have connections with the outside, as the centrepoint of a circle to the angles which can be drawn from it: well! these angles cannot remain what they are without the centrepoint and the centrepoint not without them. ${ }^{34}$

Herder's argument here does not in fact stand in contradiction to Leibniz's image of the centre as the meeting point of a number of lines. But when it is understood as Herder

\footnotetext{
${ }^{32}$ GP, VI, 609, § 17.

${ }^{33} \mathrm{Cf}$. Leibniz, Système nouveau de la nature, GP, IV, 478.

${ }^{34} \mathrm{ULG}, 226$.
} 
intends it to be, namely, as a model of the real connection between a central monad and the external world, the contradiction is clear. Analogously to the lines formed by the angles drawn from a centrepoint, Herder is now able to conceive of multiple sequences of perceptions simultaneously converging on a single point, the mind. This dynamic conception is already announced by a subtle but important difference from Leibniz in Herder's formulation: whereas Leibniz speaks in a construction-independent fashion of lines meeting at a point, Herder speaks of actively constructing the angles by drawing them from the centrepoint. In the absence of these dynamic connections, the soul simply remains in a 'perpetual dream'.

Up to this point in Ueber Leibnitzens Grundsätze, Herder has been arguing more or less along empiricist lines (the Platonist aspect of his epistemology not being prevalent in this work). The true originality of Herder's theory, however, becomes clear in the second half of his reflections as he expands on his understanding of the soul's relationship to its body. This begins at the end of paragraph three. In the Principes, Leibniz elaborates on his geometric image of the soul as a centrepoint in the following way:

each distinct simple substance or monad, which makes up the center of a composite substance (an animal, for example) and is the principle of its unity, is surrounded by a mass composed of an infinity of other monads, which constitute the body belonging to this central monad, through whose properties the monad represents the things outside it, similarly to the way a center does. And this body is organic when it forms a kind of automaton or natural machine, which is not only a machine as a whole, but also in its smallest distinguishable parts. ${ }^{35}$

Herder's conclusion to paragraph three is based on this claim, where he moves from his consideration of the geometric example of the circle to the substantial reality it is meant to represent: '[a]nd what about a substance?', he asks, 'from whose inner force it must be explained that it reveals itself, that it appears in the universe, that it can become the centre of a mass. ${ }^{36}$ Herder begins paragraph four with his own explanation of how this substance, or soul-monad, becomes the centre of a mass.

A monad should be able to change its representations, and must change them according to its basic force. Now if these representations are, however, nothing but external connections, must not the ground of the perceptibility of the external

\footnotetext{
${ }^{35}$ PNG, 598-99.

${ }^{36}$ ULG, 226.
} 
and the ground of the ever changeable perceptibility also lie in the basic force? There must therefore also be an organic body, which becomes its [i.e., the inner force's] measure, and which can be no automaton in itself. ${ }^{37}$

Herder begins from Leibniz's conception of the soul's primitive active force or substantial form and its modifications in the form of perceptions or representations. It has already been established by Herder, however, that, these perceptions are not the product of the soul's primitive active force, as Leibniz would have it. Herder is instead speaking here of how the monad is able to change its representations. In terms of the Leibnizian primitive active force or substantial form of the monad, this is the modification of that force or form qua appetition. ${ }^{38}$ Herder acknowledges, in agreement with his analysis in the previous paragraph, that the representations of the soul result from the connections to the external world, but now the problem is how the soul's 'basic force' grounds not just the changes in its perceptions or representations but also that very capacity to perceive the external world itself. The solution lies in the soul qua substantial form building a body for itself. Herder's thesis, in Leibnizian terms, amounts to the following: appetition (Herder's 'basic force'), as modification of the soul's primitive active force, entails a striving after new perceptions of the external world, which can only be obtained via the senses of a body; appetition thus manifests itself via the constructing of a body for the soul, thereby serving as 'the ground of the perceptibility of the external and the ground of the ever changeable perceptibility.'

The idea that the soul strives after new perceptions and needs an organic body through whose senses it can satisfy this striving was not new. Kant himself mentions in the Nova dilucidatio how all 'modern philosophers' agree that the soul's connection with an organic body is necessary, citing Crusius, who was, Kant notes, 'so completely of my opinion that he frankly asserts that the mind is bound by a law, according to which its striving to produce representations is always united with a striving of its substance to produce a certain external motion, so that if the latter is hindered the former is also impeded. ${ }^{39}$ More generally, it is therefore also true that Herder's commitment to soulbody interaction was not original either. By the time he was writing, physical influx of

\footnotetext{
${ }^{37}$ ULG, 226.

${ }^{38}$ For discussion of how perceptions and appetitions are both modifications of the primitive active force, see Phemister (2005) 213ff.

${ }^{39}$ AA, I, 412. Cf. Crusius (1747) 142-50, §§ 79-81.
} 
one form or another had effectively won out over pre-established harmony. ${ }^{40}$ But what was original was the specific nature of Herder's conception of the soul's relationship to the body. In order to grasp this originality, we need to situate it in its proper context.

In Crusius' radical view, beyond its capacity for thinking and desiring, the soul, like the body, possessed impenetrability and it is in virtue of this that the two were able to interact, as Kant outlines above. ${ }^{41}$ In the pre-critical Kant, we see the struggle to make sense of soul-body interaction too. ${ }^{42}$ Initially, in the early pre-critical period from the Gedanken von der wahren Schätzung der lebendigen Kräfte up until the Nova dilucidatio, Kant had construed the possibility of soul-body interaction in keeping with the Wolffian conception of space (that is, space is the result of substances acting on each other). On this account, if a substance is a being capable of active force, the soul could plausibly interact with the body via its own inner active force and the effects of that interaction would be clear for all to see in the space to which it would give rise. ${ }^{43}$ But Kant eventually comes to accept a conception of space that is intrinsically linked to the structure of matter (although it would be wrong simply to attribute a Newtonian conception of empty space to $\mathrm{him}^{44}$ ) as a result of the essential nature and internal possibility of matter which is non-morally dependent on God, as explicated in the Einzig möglicher Beweisgrund. Now in this Newtonian physical universe, the only changes we know of are those which occur as a result of the forces of attraction and repulsion, via the laws of motion, between material bodies. The pre-critical Kant is thus brought to the impasse that the only way to conceive of the interaction between the soul and the body is, like Crusius, to make the soul impenetrable and construe it as a physical monad, which is unacceptable for Kant, or to preserve its immaterial nature but at the same time be forced to admit that we have no means of obtaining genuine knowledge of its powers. ${ }^{45}$ This is the dilemma explored in the Träume eines Geistersehers where Kant entertains the possibility of a separate world of spirits governed by its own laws existing in parallel with the material world. Kant's polemical objective here is to demonstrate just how far one's

\footnotetext{
${ }^{40}$ For a good overview see Eric Watkins (2005) and the several articles by the author on the subject listed in the bibliography of his book.

${ }^{41}$ Crusius (1745) 680-88, $\S \S 362-64$.

${ }^{42}$ See Laywine (1993) Schönfeld (2000).

${ }^{43}$ See, e.g., AA, I, 20-1, § 6.

${ }^{44}$ See Reich (2001) 353ff.

${ }^{45}$ See Laywine (1993) 54ff.
} 
unbridled imagination can take one simply because of the lack of clear data about the nature of the soul. In his explanation of the work to Mendelssohn, Kant explains that we do not have any evidence of the outer 'efficacy' (Wirksamkeit) of the soul as we do with bodies whose impenetrability we sensuously perceive. That is, we do not have evidence that it is the soul moving the body in the way we do in the case of bodies moving each other. All we have experience of is the inner states of the soul, such as thinking and willing, and the mere agreement of these inner states with the external state of the body. This lack of evidence means that we cannot draw any conclusions about the forces of spiritual substances. And it is into this breach that spirit-seers like Swedenborg, the object of Kant's thinly veiled ridicule in his Träume, jump. ${ }^{46}$

The positing of a realm of immaterial spirits, however, is not the only alternative to the unattractive solution to the problem of the soul-body relationship whereby the force of impenetrability is attributed to the soul. In his published review of Kant's Träume from 1766, Herder picks up on what he at least sees as a third option which Kant briefly explores towards the end of the first chapter of his book. ${ }^{47}$ There Kant confesses his own inclination to admit the existence of immaterial natures, of which is own soul would be an example. The 'mysterious community' of the soul and body remains incomprehensible, but, Kant admits, this is only natural given that our only way of understanding external actions is mechanically, which cannot apply here, unless spirits are endowed with impenetrability. Seeming perhaps to hark back to the early pre-critical period, Kant then flirts with the possibility of what for Herder is a third way of relating soul and body.

It seems that a spirit-being is present in the matter, with which it is combined, in the most intimate fashion; and it seems not to act on those forces which inhere in the elements and in virtue of which they are related to each other; it seems rather to operate on the inner principles of their state. For every substance, including even a simple element of matter, must after all have some kind of inner activity as the ground of its producing an external effect, and that in spite of the fact that I cannot specify in what that inner activity consists. ${ }^{48}$

\footnotetext{
${ }^{46}$ Kant, Letter to Mendelssohn, 8 April 1766, quoted in Reich (2001) 355-56. Cf. AA, II, 370-71.

${ }^{47}$ For a different interpretation of Herder's review see Heinz (1994) chapter 2.

${ }^{48} \mathrm{AA}, \mathrm{II}, 327,328$.
} 
In his review, Herder begins his treatment of the first part of the Träume with a summary of this very passage, explaining how the soul can be present in the body without filling space, how the spirit-body community is mysterious because we only know of 'bodily influences', how the soul is most intimately present to the body such that it can work on the inner principle of its matter. Herder clearly approves of these hypotheses, also present in his notes on Kant's metaphysics lectures, ${ }^{49}$ which he calls 'very attractive'. ${ }^{50} \mathrm{He}$ continues with an examination of Kant's other hypothesis, also discussed in the lecture notes, ${ }^{51}$ which is considered earlier in the Träume, according to which the soul must be endowed with some kind of 'spiritual impenetrability' in order to have any effect on the body on the same model as that by which bodies causally interact with other bodies. Herder is decidedly less enthusiastic about this possibility, which, he says, depends on our unreflective familiarity with the 'bodily concepts' in which we are so wrapped up that we have great difficulty in coming up with a different kind of efficacity in space. ${ }^{52}$ The first hypothesis, whereby the soul is intimately present to the body, also lines up with comments Herder makes later in his review with respect to Kant's entertaining of a fanciful world of spirits governed by 'pneumatic' laws (whose purpose of ridicule by Kant is lost on Herder).$^{53}$ In response to the idea of a 'spirit world', whose basis Herder cannot conceive, he asks, 'might not an organic community be enough, if there are no more than souls — who would know of others? ${ }^{54}$ The clear implication is that there are no 'spirits' per se, but only souls connected to organic, living bodies.

Herder thus distinguishes himself from the standard proposals in the eighteenth century for conceiving of the soul-body relationship. These proposals all posit two distinct and separate substances which must somehow be related to each other, as the examples of Crusius and Kant both illustrate. In contrast, Herder, like Leibniz, never conceives of souls that are without a body. As he writes to Mendelssohn in 1769, "[a]re

\footnotetext{
${ }^{49} \mathrm{MH}, 146$.

${ }^{50}$ SWS, XXXII, 127-28.

${ }^{51} \mathrm{MH}, 144 \mathrm{ff}$.

${ }^{52}$ Ibid.

${ }^{53}$ We know now that the Träume and the dilemma it posed with respect to knowledge-or rather lack thereof - of the soul marked an important stage in Kant's pre-critical development which led just a few years later to the separation of the sensible and intelligible realms of the De Mundi Sensibilis atque Intelligibilis Forma et Principiis (1770).

${ }^{54}$ Ibid, 129.
} 
not both inseparably connected? I do not want to descend to the conceivability or inconceivability of a soul without a body; for on what basis do we know of a human soul existing without a body? ${ }^{55}$ Rather, Herder is returning to a more squarely, though not exclusively, Aristotelian conception of the soul as the substantial form of the body. His conception is not exclusively Aristotelian as there are two significant modern aspects to his conception. The first difference from Aristotle is Herder's acceptance of the Cartesian identification of the essence of the human soul with thought. Across several writings from the late 1760s, Herder's position is clear: it is in order fully to realize its thinking nature that the soul must build itself a body through whose senses alone it acquires perceptions and knowledge of the outside world and becomes capable of thought at all.

As he writes in Plato sagte:

The soul enters the world: the power of representation is its essence: but it is itself entirely its thought - the obscure but most lively concept of its being fills it entirely: this is its world: in this lies everything: just as the whole world is a thought in God's being. [...] [T] hus is it in this way that [the soul] prepares itself its corporeal being, just as God creates a world out of the concept of his self. ${ }^{56}$

God's relationship to the world is thus analogous to the soul's relationship to its body (we return to this point in the conclusion). Of course, this focus on the human notwithstanding, it goes without saying that for Herder there are souls at all levels of the organic world, responsible for the range of living beings that comprise it.

The second difference from Aristotle is Herder's conception of just how the soul brings about this process. Here he sides with the moderns, in particular, the Newtonian moderns, so to speak. Herder agrees with Kant that the soul does not relate to the body in virtue of some kind of impenetrability; rather, the soul is intimately present to the body, acting on it from within. The soul is able to harness the forces of attraction and repulsion, in a manner that does not necessitate impenetrability, and mechanically construct a body for itself. As Herder writes in the Grundsätze, '[j]ust like the planet-bodies in the universe are formed through the attraction- and repulsion-force: so too our soul the body: and so God the world. ${ }^{57}$ At this point in his career, Herder offers no clear explanation of

\footnotetext{
${ }^{55}$ Herder (1984) 138.

${ }^{56}$ Heinz (1994) 175.

${ }^{57}$ SWS, XXXII, 229. Cf. Zum Sinn des Gefühls (1769): 'Bloß so kann ich die Welt erklären: wie hat sich mein Körper gebildet, durch Anziehung und Zurückstoßung?’ DKV, IV, 237.
} 
just how the soul is able to employ the forces of attraction and repulsion. In a brief outline composed in 1769 , he writes:

Attraction and repulsion! I cannot explain them, I only observe them. They have probably formed the body: they preserve it: they are its essence, its nature [...] there must be a simple being that has a limited force to prepare for itself a body. As force it attracts, as limited force it is repulsed and obtains a sphere: that is its formation: the formation of a body. ${ }^{58}$

Herder's novel idea is based on the fact that what is ontologically primary for him is no longer substance, but rather force: it is in virtue of their fundamental shared element of force that the soul, as thinking-cum-forming force, and the body, as possessing attractive and repulsive forces, are able to interact. ${ }^{59}$ In the 1770 s, and in the successive versions of his epistemological treatise, Vom Erkennen und Empfinden, Herder will try to provide more adequate explanations of this interaction, which will involve construing the soul and body as both ultimately constituted of force, and thus fundamentally identical. But it is important to recognize that Herder's arguments for how the soul acts on the body, especially in the latter's formation, are different from those he marshals for explaining how the body acts on the soul - the first has more to do with active and motive forces, the latter with sensuous media and the soul as perceptually receptive. The explanations of the next decade are at first based on a deeper engagement with Leibniz's philosophy ${ }^{60}$, and then also on the new physiological ammunition Herder finds after his discovery of Albrecht von Haller's concept of irritability ${ }^{61}$ (which for Herder provides solid evidence of the soul as force pervading the body) since it is always in defence of his own version of physical influx and in opposition to Leibniz's pre-established harmony that Herder seeks to explain how soul-body interaction is plausible. Nevertheless, these future refinements notwithstanding, the intuition remains the same: the soul and the body are intimately bound up with each other and advance in complexity of structure and powers in tandem. In Leibnizian terms, Herder firmly believes, contra Leibniz, that in the living world, final causes are fully capable of really directing efficient causes.

\footnotetext{
${ }^{58}$ Gesetze der Welt: Gesetze der Körper, DKV, IX/II, 222.

${ }^{59}$ Cf. Heinz (1994) xxiii.

${ }^{60}$ See, e.g., Übers Erkennen und Empfinden in der menschlichen Seele (1774), DKV, IV, 1108-1110.

${ }^{61}$ Vom Erkennen und Empfinden, den zwo Hauptkräften der Menschlichen Seele (1775), SWS, VIII, $272 \mathrm{ff}$.
} 
Returning to Ueber Leibnitzens Grundsätze, it is in light of his unique conception of the soul that Herder rejects Leibniz's conception of the organic body as an 'automaton' in paragraph four. Leibniz had opposed all use of plastic natures, hylarchic principles, or any other immaterial principle which was meant to account for the phenomenon of life and the growth of organisms. He kept the realms of final and efficient causes strictly separate in his explanation of life and organisms. The soul, or dominant-monad, of an organism certainly reflects all the developments and growth of the body, and is the body's organizing principle of motion, providing unity to the aggregate of corporeal substances that constitute it. The soul thus had in Leibniz much the same role it has in Herder, with one crucial difference: its relations with the body are purely expressive, since the soul never actually interacts with the body. Genuine interaction, as we have already noted, would have compromised important principles to which Leibniz was committed but whose physical or metaphysical necessity no longer resonated in Herder's day: the law of conservation of force, the principles of substantial self-sufficiency, causal self-sufficiency, and substantial unity, above all. ${ }^{62}$ Although the soul's communication with the body was purely ideal, the body, as an 'automaton', was a 'natural machine'. In line with the preformation thesis, the body simply harmoniously unfolded itself according to the predetermined laws of the entelechies which governed the corporeal substances of which the body was an aggregate. The entire complex process, however, was, on the physical level, the mechanical product of entirely efficient causes, without the need for any directly acting immaterial principle-indeed, Leibniz famously claimed in Considérations sur les principes de vie et les natures plastiques (1705) with respect to Cudworth's plastic natures, 'non mi bisogna, e non me basta, because this preformation and this infinitely complex organism provide me with material plastic natures that meet the need. ${ }^{63}$ Leibniz was able to account for the complexity of the organic world by writing substantial forms into his very conception of a dynamic matter and combining this with the thesis of preformation, such that he had only need of series of efficient

\footnotetext{
${ }^{62}$ Maupertuis, for example, rejected both the Cartesian conservation of motion and the Leibnizian conservation of force. See "Lettre X. Sur les lois du mouvement" in Maupertuis (1768) 270-74. For a discussion see Duchesneau (1993) 267ff. In chapter four (259-379), Duchesneau explains how, for Leibniz, the physical world and our scientific conception of it in terms of laws of nature is undergirded by architectonic metaphysical principles (of finality, identity of indiscernibles, and continuity).

${ }^{63}$ Considérations, L 589. For a full discussion, see Duchesneau, 'Leibniz et le concept d'organisme' in Duchesneau (1998) 315-72.
} 
causes operating in a purely mechanistic framework at the physical level of explanation. Herder, in contrast, starts with a Newtonian conception of matter, modified by Kant to possess inherently both attractive and repulsive forces, and the laws of motion that result, and develops a novel and unique way to understand the living world. The heart of this new theory is Herder's double-conception of the soul as thinking substance and as substantial form. This conception grew out of 1) Herder's agreement with Leibniz's understanding of the close - albeit erroneously ideal—connection between the soul and body, seen in Leibniz's discussions of life and the living world as well as in the the Nouveaux essais (written in 1704, but only published in 1765) on which Herder took copious notes, and its epistemology of confused and obscure ideas and petites perceptions, 2) his dissatisfaction with 'immaterial principles' such as plastic natures, or Buffon's moules interrieurs, which left so much of the soul-body relationship unexplained - as opposed to explaining too much, as it were, for Leibniz - and 3) his dissatisfaction with theories of the soul-body relationship premised on two separate and distinct substances as seen in Crusius and Kant.

In relation to (2), it is important to note further that Herder's theory, while embracing a metaphysical account that goes beyond budding vitalistic accounts, nevertheless draws on the latter. Herder was not yet familiar with the most obvious vitalist and epigeneticist source available to him, namely, Caspar Friedrich Wolff's Theoria generationis (1759), which posited a vis essentialis as the formative force of an organism, for Herder read Wolff only in the $1780 \mathrm{~s} .{ }^{64}$ But he was familiar with John Turberville Needham's work, from whose Observations upon the generation, composition and decomposition of animal and vegetable substances (1749) Herder made excerpts in 1765 . Herder notes that Needham posits a 'productive faculty' in nature, a 'vegetative force' that is the basis of all generation. Herder further observes Needham's explanation of the operation of this force by 'division and composition' and 'expansion' ${ }^{65}$ In the 1770s, Herder will elaborate on how the body of an organism grows via the expansion and contraction of its living fibres in search of nutrition. Early on, therefore, Herder was aware of and influenced by epigenetic and vitalist theories.

\footnotetext{
${ }^{64}$ See Nisbet (1970) 203ff.

${ }^{65}$ SWS, XIV, 663.
} 
Nevertheless, what is missing in such theories is the metaphysical basis so central to Herder's early account by which the soul is the ultimate directing source of the forces invoked by these theories.

The remainder of paragraph four in Ueber Leibnitzens Grundsätze further exposes the implausibility of the pre-established harmony of the soul and body. If the organic body is conceived of as an automaton, then this amounts to positing the existence of a soul which must be able to influence its body in order to acquire and change its representations but whose body alone contains the grounds of its movements. ${ }^{66}$ As Herder asserts, this would be a contradiction. Framing his criticism anew in the language of $\S 3$ of Leibniz's Principes, the relations of a mirroring monad and a mirrored universe make no sense if there is no real communication between the two, i.e., if the monad's mirroring is able to be generated entirely from itself and if the universe is not actually reflected. ${ }^{67}$ There has to be an 'inner reason in each soul', Herder continues, why each part of the universe it oversees (i.e., its body) is there which does not have to be sought in a third being (i.e., God) as the ground of both. Filling in the terms he implies with letter symbols ${ }^{68}$ Herder asks: what would it be if the soul did not exist for the sake of the body and the body not for the sake of the soul, but rather both for the sake of God, for whom it was nothing but a game that neither existed for the other and yet both appeared to? Again, Herder is invoking the spectre of Descartes' deceitful God from the Méditations. In fact, Herder is on this point in agreement with Descartes for whom the actual union of the soul and body was a reality confirmed by our sensation of it, even if Descartes' dualism is otherwise inconceivable for Herder.

In the final fifth paragraph of Ueber Leibnitzens Grundsätze Herder turns to confront Leibniz squarely on the question of life itself. In $\S 4$ of the Principes, Leibniz claims that there is life everywhere, joined to limbs and organs, and that each monad,

\footnotetext{
${ }^{66}$ 'There must therefore also be an organic body, which becomes its [i.e., the inner force's] measure, and which can be no automaton in itself: otherwise $a$ would be posited such that it could not be without having to influence (würken) $b$, and $b$ would in turn be posited as the sole ground of its efficacity (Würkung), which is a contradiction.' ULG, 226.

${ }^{67}$ ULG, 226.

68 'Was wäre es, wenn $a$ nicht um $b$ wegen, und $b$ nicht um $a$ wegen, sondern beide um $c$ wegen exsistirten, der nichts, als ein Spiel darinn hätte, daß $a$ nicht um $b$ und $b$ nicht um $a$ exsistirt, und doch beide für einander zu exsistiren scheinen.' ULG, 226.
} 
together with its body, makes up a living substance ${ }^{69}$ This proves too much for Herder and he makes no attempt to hide his sarcasm. 'Everywhere there is life: everywhere life joined to organs', Herder repeats and then goes on to ask, 'and where would the ground of this connection lie? not in life, not in the organs: where then? A Deus ex machina must be called upon, who contains the ground of the connection of both, such that these of course contain nothing of it, and this is a contradiction. ${ }^{70}$ The contradiction is selfevident: if God must be called upon to effect one mammoth miracle at the very beginning as a result of which bodies and souls will henceforth unfold according to their own laws and appear to interact but not actually do so, then this can hardly correspond to what we know of as 'life'. Echoing passages from $\S 3$ and $\S 4$ of the Principes, Herder continues in the same vein:

A monad is supposed to rule over others, and over many others, without it being the case that in each of these [monads] would be [found] the reason/ground for the changes in the others. A monad is supposed to increase in its forces in the same degree as its body organizes itself, and this increase, which always occurs together, should contain nothing for the other: not an efficient cause, not an indispensable condition, merely simultaneity - how unbelievable! $!^{71}$

These youthful expressions of wonder at Leibniz's system betray an obvious failure to appreciate the philosophical and metaphysical framework within which Leibniz saw himself as operating as he set about trying to account for the material and organic world. But against the background of Herder's developing philosophical convictions and intellectual context as explored in this article, they should appear decidedly less shallow. Herder continues his rant to the very end, expressing his amazement that Leibniz even speaks of how the sense-organs of the body receive contrasting and distinct impressions which in turn correspond to contrasting and distinct perceptions in the soul, and yet all this 'without inner ground', without real interaction. ${ }^{72}$ Indeed, there is one ground that could explain all these effects, Herder proclaims, 'it would appear to me that the world would be incomparably simpler and diverse if the ground of its connection and of all of

\footnotetext{
${ }^{69} \mathrm{PNG}, 599$.

${ }^{70}$ ULG, 227.

${ }^{71}$ ULG, 227.

${ }^{72}$ ULG, 227; PNG, 599.
} 
its changes were in each monad ${ }^{73}$. With this seemingly slight modification to the Leibnizian position, but one which makes all the difference, Herder concludes his critique.

The unique conception of the soul-body relationship that Herder develops in the 1760s and to which he remains faithful for the rest of his life thus bears a complicated relationship to Leibniz. While it is predicated on the rejection of the windowlessness of monads and pre-established harmony, it draws on Leibniz's conception of the close relationship between soul and body. Herder's theory, therefore, goes far beyond the other attempts in the eighteenth century to account for the phenomenon of life. Unlike any kind of simple immaterial organizing principle, Herder's theory involves a double-conception of the soul as thinking substance and substantial form. Leibniz's epistemology powerfully informs this double-conception.

Leibniz's influence, however, can also be felt in one further way: through his Platonist metaphysics. ${ }^{74}$ The soul is not simply an Aristotelian principle of life, but rather a divine emanation of God himself. And it is in how Herder adapts the Leibnizian conception of the soul as divine, in how his conception of the soul-body relationship bridges the gap between spirit and matter, metaphysics and physics, that his real significance and originality lies. For it is here that can be seen most clearly how Herder's theory transcends philosophical accounts of the relationship between the two distinct substances of the soul and body on the one hand, and the biological theories of epigenesis and vitalism on the other. On Herder's account, God fulfills himself through realizing all that is possible in his divine thought and creating the universe, which includes the creation of finite human souls. These souls are necessarily joined to bodies which they construct for themselves analogously to God creating the external world. Through their sensuous interaction with the world and other beings, the language, knowledge, and culture that these souls then collectively develop, over the course of history, amount to a spiritualization of the material universe, which is thereby brought back to God. This account is worked out by Herder in the 1770 s, and it will later exercise a profound

\footnotetext{
73 'mich dünkt, die Welt würde ungleich Einfacher und Vielfacher, wenn in jeder Monas der Grund ihrer Verknüpfung und aller ihrer Veränderungen ist'. ULG, 227 (emphasis added).

${ }^{74}$ For a discussion of Leibniz's Platonist assumptions and metaphysics, see Mercer (2001) 173-254.
} 
influence on the course of German philosophy. For, as Panajotis Kondylis has argued, Herder's thought showed the way through to a reconciliation of matter and spirit, the physical and metaphysical, the sensuous and the normative, by construing the former in each of these dichotomies as the vehicle of the latter such that the dichotomies themselves dissolve. ${ }^{75}$ The objective of this article has been to demonstrate how the seeds of this fateful reconciliation lie in Herder's early engagement with Leibniz, where it assumes the form not just of a reconciliation but in fact of a close connection of the Leibnizian realms of final and efficient causes through Herder's working out of his particular conception of the soul-body relationship in the little known piece Ueber Leibnitzens Grundsätze.

Université de Montréal

${ }^{75}$ Kondylis (1981) 615ff. 


\section{Bibliography:}

1. Primary sources

Crusius, C. A. Entwurf der nothwendigen Vernunft-Wahrheiten (Leipzig: 1745 /

Hildesheim: Olms, 1964).

Crusius, C. A. Weg zur Gewissheit und Zuverlässigkeit der menschlichen Erkenntnis (Leipzig: 1747 / Hildesheim: Olms, 1965).

AT: $\quad$ Adam, C. and P. Tannery (ed.) Oeuvres de Descartes (Paris: Vrin, 1996).

SWS: $\quad$ Suphan, B. (ed.) Herders sämtliche Werke (Berlin: 1877-1913 /

Hildesheim: Olms, 1967).

DKV: $\quad$ Bollacher, M., et al (ed.) Herders Werke in zehn Bänden (Frankfurt:

Deutscher Klassiker, 1985-2000).

Herder, J. G. Briefe, ed. Wilhelm Dobbek and Günter Arnold (Weimar: Böhlhaus Nachfolger, 1984).

Herder, J. G. Herder und die Anthropologie der Aufklärung, ed. Wolfgang Pross (Munich: Carl Hanser, 1987).

Kaestner, A. 'Préface' in Leibniz, Oeuvres philosophiques, ed. Eric Raspe (Amsterdam: Schreuder, 1765).

AA: $\quad$ Königlich preußische Akademie der Wissenschaften (ed.) Kants gesammelte Schriften (Berlin, 1910ff.).

Kant, I. Theoretical Philosophy 1755-1770. David Walford and Ralf Meerbote (ed.) (Cambridge: Cambridge, 1992).

GP: $\quad$ Gerhardt, C. I. (ed.) Die philosophischen Schriften von G. W. Leibniz, 
(Hildesheim: Olms, 1965).

L: $\quad$ Loemker, L. E. (ed.) G. W. Leibniz: Philosophical Papers and Letters

(Dordrecht: Riedel, 1969).

Maupertuis, P. L. Euvres de Maupertuis (Lyon: Bruyset, 1768).

Wolff, C. Anmerckungen zur Deutschen Metaphysik (Frankfurt: 1740 / Hildesheim: Olms, 1983).

Wolff, C. Vernünfftige Gedancken von Gott, der Welt und der Seele des Menschen, auch allen Dingen überhaupt (Magdeburg: 1751 / Hildesheim: Olms, 1983).

\section{Secondary Sources}

Adams, R. M. Leibniz: determinist, theist, idealist (Oxford: Oxford, 1994).

Arnold, G. ' „,... der größte Mann den Deutschland in den neuern Zeiten gehabt' Herders Verhältnis zu Leibniz', Studia Leibnitiana, 37 (2005) No. 2: 161-85.

Clairmont, H. and Marion Heinz, 'Herder's Epistemology', in A companion to the works of Herder, edited by Hans Adler and Wulf Koepke (Rochester: Camden House, 2009) 43-64.

Dreike, B. Herders Naturauffassung in ihrer Beeinflussung durch Leibniz' Philosophie (Wiesbaden: Steiner, 1973).

Duchesneau, F. Les modèles du vivant de Descartes à Leibniz (Paris: Vrin, 1998).

Duchesneau, F. La dynamique de Leibniz (Paris: Vrin, 1994).

Duchesneau, F. Leibniz et la méthode de la science (Paris: PUF, 1993).

Friedman, M. Kant and the exact sciences (Cambridge: Harvard, 1992).

Garber, D. Leibniz: body, substance, monad (Oxford: Oxford, 2009). 
Heinz, M. (ed.) Herder und die Philosophie des deutschen Idealismus (Amsterdam: Rodopi, 1997).

Heinz, M. Sensualistischer Idealismus: Untersuchungen zur Erkenntnistheorie und Metaphysik des jungen Herder (1763-1778) (Hamburg: Meiner, 1994).

Kondylis, P. Die Aufklärung im Zeitalter des neuzeitlichen Rationalismus (Stuttgart, 1981 / Hamburg: Meiner, 2002).

Laywine, A. Kant's early metaphysics and the origins of the critical philosophy (Atascadero: Ridgeview, 1993).

Nisbet, H. B. Herder and the philosophy and history of science (Cambridge: MHRA, 1970).

Mercer, C. Leibniz's metaphysics: its origins and development (Cambridge: Cambridge, 2001).

Phemister, P. Leibniz and the natural world: activity, passivity and corporeal substances in Leibniz's philosophy (Dordrecht: Springer, 2005).

Reich, K. Gesammelte Schriften, Manfred Baum et al (ed.) (Hamburg: Meiner, 2001).

Renaut, A. 'Introduction' in Herder, Histoire et Cultures, ed. Renaut (Paris: Flammarion, 2000) 7-39.

Schönfeld, M. The philosophy of the young Kant: the pre-critical project (Oxford: Oxford, 2000).

Watkins, E. Kant and the metaphysics of causality (Cambridge: Cambridge, 2005).

Zippert, T. Bildung durch Offenbarung: das Offenbarungsverständnis des jungen Herder als Grundmotiv seines theologisch-philosophisch-literarischen Lebenswerks (Marburg: Elwert, 1994). 